\title{
Editorial
}

\section{Christopher CHIPPINDALE}

8 Published simultaneously with this issue is an extra special number, Transitions, a collected set of papers on the theme Pleistocene to Holocene in Australia \& Papua New Guinea, edited for ANTIQUITY by JIM ALLEN \& JAMES F. O'CONNELL. It is a rare opportunity for a number of this journal to focus on one defined subject, achieved by upping the total of pages we print this year, and reserving some for this thematic attention. Like any ANTIQUITY contribution, its specific subject will not fall in the defined interest of any one 'average reader'. Confident in our readership's willingness to take notice of good archaeology, wherever and whenever it is done, we hope Transitions is not another unnecessary edited volume, of the kind we sometimes grumble about. I know its subject is placed in space and time at some distance from most of where you are and we are. It seems to me that its combination of field energy and considered analysis, real-world fact and imaginative ideas, care both for the particulars of the matter and equally for larger themes, steady study within proven frames of reference and an awareness of the limits of those frameworks - these ought to be universal to archaeological research: that is why we call it simply Transitions rather than One Particular Transition. It makes a solid book, fatter than the ANTIQUITY production budget would like - but anything weighs that amounts to a real study of a large subject by methods better than arm-waving.

80 One of the cable TV channels that now infests the Chippindale household has a section called 'No comment'. It just shows current news film, usually of unpleasant events, without introduction, justification or apparent mission to explain it to you: the stuff is briefly labelled and supposed to speak fairly for itself. I make practically no comment on two contributions to this issue which go closely together: in the Reports, TIM MURRAY \& JIM ALLEN (La Trobe University), 'The forced repatriation of cultural properties to Tasmania', on an unhappy break-down of working relations for the prehistory of that island; among the Papers, ROCER ANYON \& T.J. FERGUSON writing on 'Cultural resources management at the Pueblo of Zuni, New Mexico, USA', on the longest-standing programme under which a native American tribe directs and contributes to the study of archaeology in its country.

The two belong together, as extreme instances from a range of current experience in this most difficult of issues, the relations between indigenous peoples and the research archaeologists who address the ancient history of their lands. It has been a growing preoccupation of the decade and will be into the new millennium.

One immediate point is clear. Where indigenous people feel uncertain of their identity, pressured to justify their self-definition, insecure in their land, tested in their links to what they know is culturally theirs, marginalized amongst aliens, and when the archaeological issues are mixed up with the tensions of wider society, matters may be hard. Where indigenous people are confident in their identity, accepted in their self-definition, secure in their own country, respected in their cultural values, confident in their ethnic standing, and when the common interest of indigenous peoples and of archaeologists are understood and reserved a little from other and divisive issues, then it may be less tough. It will never, and with good cause, be all sweet and easy.

8 The story of Stonehenge, a monument as small in its physical dimensions as its fame is large, has uncannily followed the wider story of common archaeology. Naturally, the same goes for its 20th-century excavations, a sometimes-sad chapter which is now brought to a bright and good close in a manner quite unexpected only three years ago. The century began well, with the mining engineer and archaeologist William Gowland making neat, small and instructive incisions when the great 

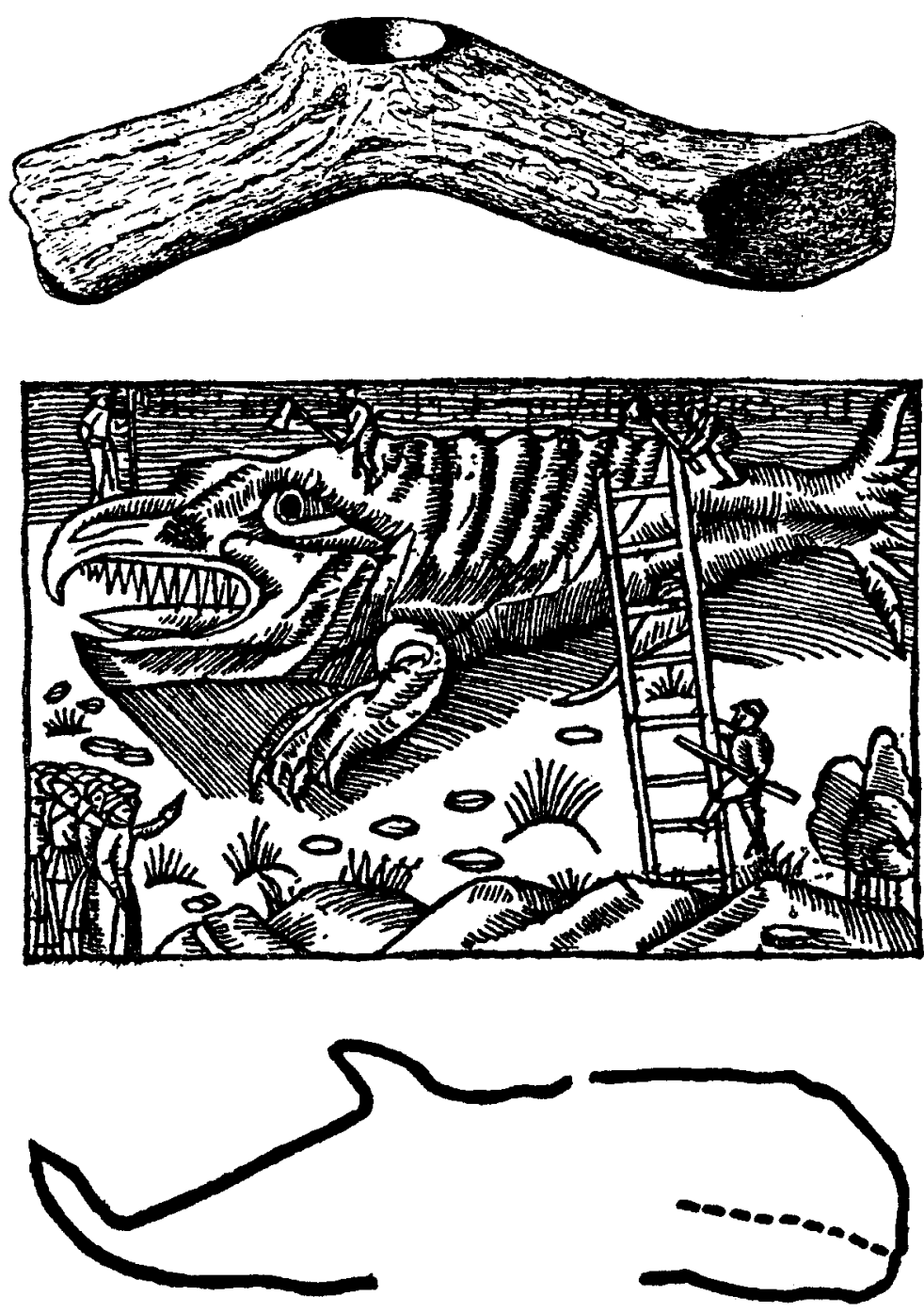

Professor Sir GRAHAME CLARK, born 28 July 1907 , died on 12 September 1995.

These three illustrations come from his ANTIQUITY paper, 'Whales as an economic factor in prehistoric Europe (1947), one of several published here and in the Proceedings of the Prehistoric Society, which were built into Clark's great Prehistoric Europe: the economic basis (1952).

Above: prehistoric axehead found against the skull of a rorqual stranded and butchered at Meiklewood, on the Firth of Forth.

Centre: print from Olaus Magnaus, of a rorqual stranded near Tynemouth, northeast England, in 1532; it is being cut up with iron tools, historic equivalent of the stone tools at the Forth sites.

Below: prehistoric rockengraving at Strand, Norway, of a pilot-whale.

Grahame Clark, Disney Professor Emeritus of Archaeology in the University of Cambridge and master of a world and of an economic prehistory, was also master of a Cambridge college. So, by college tradition, his coffin after the funeral service was processed around the Peterhouse court, the Fellowship following in pairs behind. leaning stone 56 was set upright (his trenches made parch-marks in the Stonehenge grass, during the summer of 1994). William Hawley dug for the Ministry of Works and the Society of Antiquaries, 1919-26, aimed for those same good standards, but drifted off them; by degrees, too much came to be dug for no defined purpose and with no clear result. From 1950, Richard Atkinson and colleagues dug again, among their motives the need to report better the previous excavations. But their fieldwork was not published as such either, although Atkinson's interpretation of it was published in his little classic Stonehenge (1956), until this year necessarily the standard text. Atkinson, an early casualty of the disease superadmini- strativitis now endemic in universities, reached a point, as he told me, that it was Monday mornings alone that were kept for teaching and archaeology, the rest of the week being swallowed by other business. Stonehenge remained unpublished at his death in 1994, a 'crime against science' as he had with admirably clear vision named the non-publication of digging in his Field archaeology (1946).

An end to that sad story and into the bright.

Stonehenge reached a stage, then, that it had been excavated in some part during 35 years of the century - more than one year in three. There had been 123 separate cuttings. The field-records and materials were dispersed, and the possibility of full knowledge was avail- 
able to no one. English Heritage, proprietors of the monument itself, had been quietly gathering the scattered records into a single consolidated archive in Salisbury Museum. At the energetic behest of its chief archaeologist, GEOFFREY WAINWRIGHT, supported by his chairman, Jocelyn Stevens, Wessex Archaeology was commissioned in early 1993 to produce a consolidated report on the archaeology of Stonehenge. Little more than two-and-a-half years later - the period some books take to grind through the press - a packed meeting of the Antiquaries heard ANDREW LAWSON of Wessex Archaeology summarize the report findings and see the first copies: the 620-page, double-column large-format Stonehenge in its landscape: twentieth-century excavations by Rosamund M.J. Cleal, K.E. WALKer \& R. MONTAGUE. * As well as the gathering of so many scattered threads, new patterns are discerned in the collected weave, and substantial new research. There proving to be only 10 trustworthy radiocarbon dates, of which just 5 referred to the central monument, a set of 42 new determinations was made as the basis of a new carbon chronology for prehistoric Stonehenge. Another astonishment is that there was no upto-date or accurate plan of the place, a lack now filled (and a three-dimensional photogrammetric survey of the standing features as well). There will be review notice of the book in our 1996 volume: meanwhile we salute the fast work that has made of Stonehenge an archaeologically honest monument once more.

One could imagine the moral: if you want something actually to be done, engage an archaeological business, not an academic.

The Stonehenge surroundings remain the unhappy mess which MPs fairly called a 'national disgrace'. Efforts to make a good and honest transformation there remain stuck in a mud of obstacle. When there is at last a resolution, or real forward progress, or just cause for eternal dismay, we anticipate a report here.

\footnotetext{
* Its supporting 'major contributors' should be mentioned: on the title-page are also named Michael J. AJllen, Alex BAYLISS, C. BRONK RAMSEY, LINDA COLEMAN, JULIE GARDINER, P.A. HARDING, RUPERT HOUSLEY, ANDREW J. LAWSON, GERRY MCCORMAC, JACQUELINE I. MCKINI.HY, ANDREW PAYNE, ROBERT G. Scaffe, Dale SERJEANTSON \& GeOFF WAINWRIGHT. The full cast for the 20th-century drama would more than fill a page, starting with Richard Atkinson's colleagues in the 1950s excavations, STUART PIGGOTT and the late J.F.S. STONE, and Atkinson's latter research assistants, MARGARF"' EHRENBERG and PETER BERRIDGE.
}

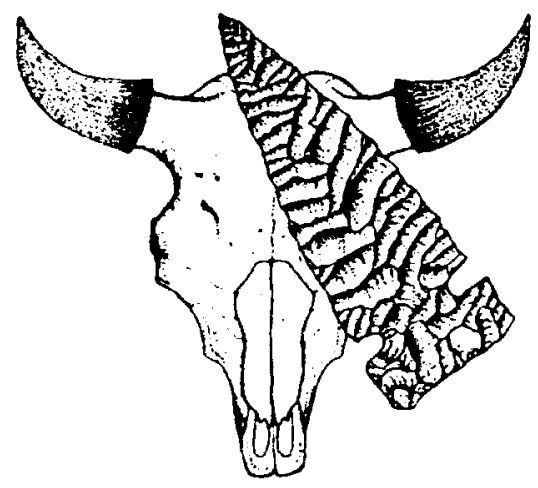

Emblems of Plains archaeology: bison skull and edge-notched projectile point.

Logo for the 53rd Plain Conference, adapted from the design for the Vore Buffalo Jump Development Campaign, by Charles A. Reher.

It is years since I went to a US regional conference, so I looked forward to the Plains meeting held at Laramie, Wyoming, in late October. It was a cracker: efficient, thoughtful and courteous organization; genial and friendly atmosphere; some first-rate papers and sessions; a good mix of subjects; a strong student contribution encouraged by a prize for best student presentation (won by BRUCE LOW, University of Saskatchewan). The registration fee was reasonable, I believe (I have no memory of having paid it). It was a bigger meeting than I had expected, with 30 sessions (posters included) in two-and-a-half days, and over 500 delegates: but then the American Plains are a large as well as a wide-open space, near a fifth of the continent. The treasurer's report at the business meeting, tightly scheduled before the conference banquet to discourage distraction, was a short gem of confident nerve: 'Membership stable. Reserves at year's start $\$ 90,000$, reserves at year's end $\$ 90,000$. Any questions?'

Laramie was as myth (and The man from Laramie) would promise. A little city on the high, short-grass plains, over 7000 feet up and under a strong blue sky; to the west the snowcovered Rockies, to the east the plains that run beyond the sky and far on to the Missouri. The transcontinental railroad made the place, bringing its living city - a 'Hell on Wheels' - there in 1868. The Union Pacific still hoots through town, trains of cars near a mile long hauled by two, three, four, five, seven locomotives. I hoped to see and to eat buffalo (to complement the European bison I enjoyed last year) but the Overlander café's chosen exotic of the week 
was alligator, not what Wyoming stands for in my vision. A more pertinent reminder of real hunter-gatherer life on these high plains was a short hour spent walking across empty country in blowing snow as the first of the winter's storms came through to block all the highways out of town. MARCEL KORNFELD, his dog and I between us came across one rabbit and, later in the truck, a little bunch of four buck antelope; I would not have liked my survival to have depended on our catching them. The University is unexpectedly handsome, fine buildings in pinky-tan sandstone, the older ones with good Art Deco detailing.

Special to this year's conference were celebrations in honour of GEORGE C. FRISON, high master of the Archaic archaeology of the Plains, on the occasion of his retirement from the University of Wyoming. He was well 'roasted' in long and mischievous speeches at the banquet, with a fine show of embarrassing slides: reading his standard Prehistoric hunters of the High Plains (2nd ed., 1991) shows how solid and acute his studies have been. From the early days of his experimental archaeology were the pictures - so famous even I have heard of them - from that day when the boys at Wyoming had word of a circus elephant that had died on tour in Denver. Down they went to try their hands with atlatl and stone projectile-point; it was June, and the poor beast was beginning to go off as her carcass was dangled, upside-down from a crane in the renderer's yard, for penetrative practice and measured measurement. Good things came of that caper, and the more planned studies in Africa that followed.

Given the Plains' environment and Frison's research interests, I had expected much at the meeting from the manly world of bison-kills, early projectile-points and the mass-killing deposits in bone-beds below the buffalo-jumps. So it proved. By my arithmetic, there were 78 papers on these archaic themes, 139 on other aspects of archaeology, just 54 on other historical and anthropological topics. (Although this was the 53rd Plains Anthropology Conference, there was little - to my surprise - on the rich ethnography and contact-period ethnohistory of native Americans in the Plains.)

I enjoyed papers on the technical aspects of the bone-beds - the stratigraphy, nature and context of these remarkable deposits, in which great spreads of bones (usually bison, for the most part) seem to mark the killing-places from the bison-drives. Energetic researchers, very much following the agenda of LEWIS BINFORD's best book, Bones: ancient men and modern myths, continue to plough a vigorous, self-consciously scientific, way through difficult issues of site formation and taphonomy. Frison's strategy, of making limited excavation at each site, with a view to re-analysis and in due time to re-excavation, proves valuable. There was good stuff, though I would have enjoyed attention being visibly paid also to the social issues: how were these collective hunts organized if collective hunts they really were? what social mechanisms gathered enough people together when there were scores of carcasses all of a sudden to butcher, and tons of flesh to cure and dry on racks whilst it was still meat? Alongside the palaeo-biology, the measurements, the statistics, I enjoyed the living touch of MARK MILLER, the Wyoming State Archaeologist; a mob of young cattle on his father's ranch had given him the chance to see how easily a herd could be driven into the closed end of an arroyo and trapped there. (Easily.) Trapped they were, so tight he could have walked across the little valley on their backs. George Frison's researches, having studied killing rather than how you got the critters out alive, offered no intelligence as to what Miller should do next, nor how he should explain to his dad why the steers looked thinner than before the afternoon's business.

There are nine sites now with public displays in place or planned, from Lubbock Lake in west Texas, up to the Head-Smashed-In buffalo-jump in south Alberta, and beyond. HeadSmashed-In is an ambitious display as telling as its name, a great gully cut down through the slope and covered with a high glass roof; beyond the buffalo-site, it has first-rate displays of indigenous Plains life, a notable Native American participation in what the visitors see and who they meet (also, splendid T-shirts). You go up from this artificial space and out on to the plateau, into cool constant wind, to see the little aligned cairns that mark the buffalo drive-ways and to get some sense of the empty wide spaces this human landscape, as socially experienced, once filled.

Another of those places now planned for a public display is the Hudson-Meng site, in Sioux County, Nebraska. Papers at a good symposium addressing on-site interpretation showed the real research difficulties of these 
puzzling deposits. How does one plainly present expert knowledge when the experts dispute basics of what we know? The presenter of one paper, taking off his jacket and rolling up his sleeves as he came to the podium, had been diverted from his planned subject, public interpretation of the Hudson-Meng site, by his predecessor, who questioned whether it was an archaeological site at all - rather than a palaeontological deposit arising from some kind of a natural die-off, over which worked lithics had fortuitously been introduced in a subsequent deposit. When a slide in a taphonomy session (seven papers on bison, one on large bovids, one on lions) illustrated how grossly the first vertebrae of male bison are enlarged over the females', thanks to their masculine habit of cranial confrontation, I mused if the same observation might apply if one were to study the cervical vertebrae of male Plains archaeologists.

Reminder of the consistent finding from hunter-gatherer studies for the temperate zone - that it is the women's gathering which provides the actual majority of human subsistence - came in an acute paper by my host JULIE FRANCIS (another Frison student). Bulk rootprocessing was evidenced by a massive find in an exposed road-cut of ash and burnt stones from an oven - the less visible, and the less cervically and vertebrately challenged aspect to Plains archaeology.

In the June issue (pages 231-7), we printed PAUl BAHN's report, 'Cave art without the caves', on the astonishing series of open-air rock-art sites discovered in the Côa Valley, central Portugal; on the threat to the sites of the new dam, of Vila Nova de Foz Côa, now under construction which would flood them under many metres of water; on some of the machinations surrounding their archaeological recognition; and on the vigorous public campaign to stop the dam and save the sites.

The summer has seen large developments. Work on the dam came nearly to a halt, and it was anticipated that the new Portuguese government, taking office after national elections on 1 October, would choose between its three options: to abandon the dam in light of the rock-art; to proceed with the dam and flood the figured panels (with, presumably, some advance survey and record of what would be drowned); or to seek to salvage the figures by cutting engraved panels out of the schist bedrock. As this editorial is being typeset, on 7 November, no decision has been announced.

Electricidade de Portugal (EDP), the national utility promoting the hydro-electric dam, had the sensible idea of determining whether the rock-engravings really were ancient, and therefore did actually amount to a heritage so precious they were an absolute obstacle to their great project going ahead. After advice had been taken - UNESCO was involved and JEAN ClotTEs, the special inspector of Palaeolithic rock-art for the French Ministry of Culture three (later four) researchers visited the Côa valley, to make direct-dating studies of figured surfaces. Their results surprise all those who saw the Côa figures as consistent with Palaeolithic art as it has been known for a century in caves and, since 1981, also at open-air sites in Iberia and in Pyreneen France.

We print in this issue two articles on dating the Côa. In the first, ROBERT BEDNARIK, one of EDP's direct-dating team, * summarizes the four researchers' work, and sets out his vigorous conclusion: their work in the Côa shows the figures are only a few millennia old, perhaps even a few centuries, or even a few decades; the proof renders many archaeological pronouncements about Palaeolithic rock-art meaningless, makes an obituary to stylistic dating of Palaeolithic rock-art, and de-rails the obsolete juggernaut of conventional archaeology. In the second, JOÃo ZILHÃO, of the Lisbon Institute of Archaeology and a long-time researcher in the Palaeolithic of Portugal, critically examines the direct-dating work; finding it full of inconsistencies, presumptions and nä̈vetés, he is not persuaded the Palaeolithic date for the Côa figures is wrong that has been deduced from their nature and context.

\footnotetext{
* The 'full technical reports' about the Côa dating work done by ALAN WATCHMAN and by ROBERT BEDNARIK are to appear in Rock Art Research 12(2), Bednarik reports below; and he says there will be a general discussion paper in the Comptes Rendus de l'Académie des Sciences de Paris. I do not know where, or if, reports on their work by FRLD PHILLIPS and RONALD DORN will be made public. JOÃO ZILHĀO's article here is shortened from his paper presented to the September 1995 rock-art congress in Turin; it appears in full in Trabalhos de Antropologia e Etnologia.

Not surprisingly in the small world of archacology, and within it the smaller world of rock-art studies, I know personally several of those involved, and others from their published work. Several are contributors to ANTIQUITY. As usual, one attempts to set aside the personal factor.
} 


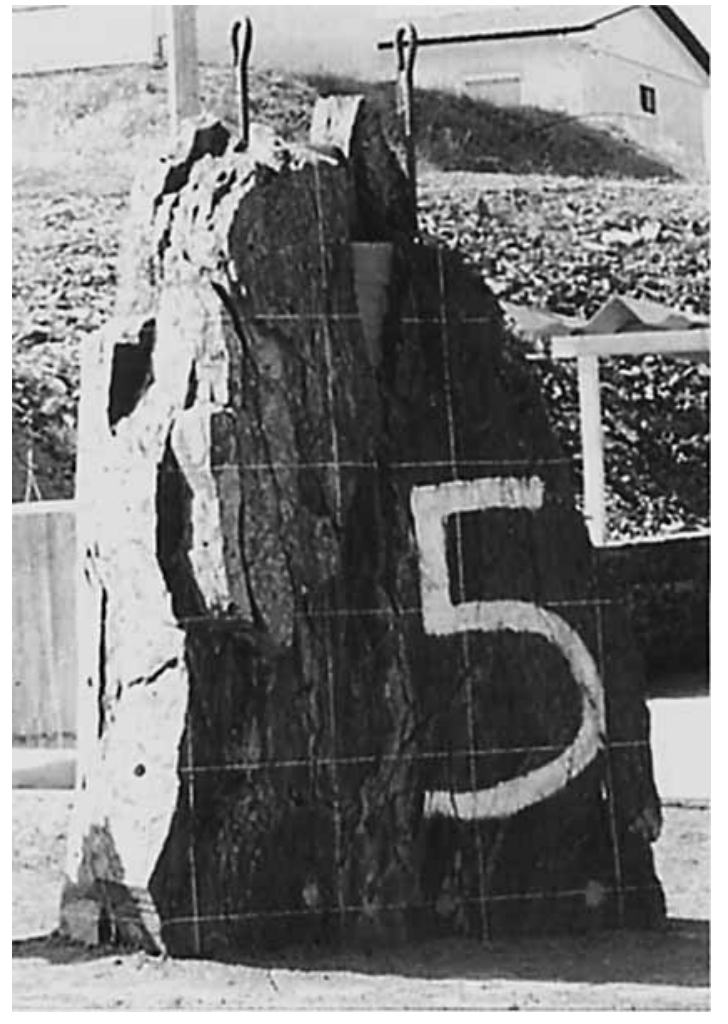

A test of the feasibility of cutting out engraved figures from the Côa valley rocks and removing them above the waters of the new dam.

Electricidade de Portugal (EDP) practised on this (undecorated) slab which, numbered 5, now stands outside their Vila Nova de Foz Côa office.

Photograph by Stuart Reevell.

Both authors sent articles to ANTIQUITY for consideration in late July; both have been substantially revised, and I have worked in the usual way with both authors to arrive at the final texts printed here. Dr BEDNARIK's includes, at my request, a fuller account of just what the four individual researchers did and found; Dr ZILHÃO's is shortened, at my request, from his full revised text. Neither has seen the other's contribution. I have placed both in the Reports section, the part of the journal normally reserved for brief contributions on current topics, rather than amongst the research articles that are accepted for publication in the light of referees' advice; no conclusions should be drawn from their relative lengths as printed, or from the order in which they appear.

I leave it to readers and, in time, to further work and to history to decide truths in the matter. JEAN CLOTTES' best guess in May this year, before the direct-dating studies, was: 'a number are Upper Palaeolithic; lots of others are undoubtedly more recent' (letter to ANDREW LAWSON, 28 May). PAUL BAHN was quoted in the Times (13 July), after EDP had announced its understanding the Côa figures were not ancient, saying: 'All the techniques they used to date the engravings are unproven and very uncertain. . . . EDP should not put much store in their conclusions. They are not only improbable, they are impossible.'

8 The archaeological view on the Côa is straightforward enough. Whatever the date of the figures turns out to be, these are precious things, to be safeguarded. Some may think a long pause, even 10 years, is necessary to allow them to be properly recorded before the barrage is built and they are flooded. I have less confidence myself that any 'full' and 'objective' record made that way would suffice. Too many rivers have been dammed and damned to insufficient purpose or benefit, and at excessive short- and long-term cost, so let us leave this great river in its proper state.

Think instead about the issues from the viewpoint of the developer, EDP. This, the national electric company, has already sunk a huge sum, committed a further huge sum, and elaborated large plans for its grand development programme. Then these pesky scratchings turned up, after some funny goings-on, and a great noise is now being shouted around them. But are they really ancient and precious - the way the zealots try to insist? So EDP has followed the best advice in finding the world's best experts on rock-art dating and bringing them to the spot, each to make their own expert study. They come from different countries. They use different techniques. They work separately, each on their own, so as to be properly independent. They produce slightly different results, to be sure, but the message that comes over when ROBERT BEDNARIK presents a collected view is: 'All reports stressed that the Palaeolithic-style engravings were certainly under 3000 years old.' So the figures that this world-wide fuss has been created over are the littlest local curiosities! They are certainly of no great age, and not to be inflated into that famous body of Franco-Cantabrian rock-art from the high Palaeolithic which is the first founding glory of western art. You have to be an archaeologist to be concerned for them! 
What should EDP, as a nationalized national utility, do? It can reasonably feel a responsibility to push forward with this development if it still has confidence in the economic sums. Many millions of pounds are already put into the project. The experts have exploded the pretence this wretched stuff is old and precious.

83 This would be fine, sort of, in a miserable way, if one had confidence in the frame of thinking that the visible leaders of the science team bring to the Portuguese affair. What worries me is the 'spin' - to use a telling word from British politics, in which the 'spin-doctor' is the public-relations wizard whose task is to send such facts of the matter as may exist spinning safely away in the direction desired.

In rock-art studies, ROBERT BEDNARIK is everywhere, always full of energy, always promoting the interest. He edits the publications of the archaeological society for the state of Victoria, and the journal Rock Art Research, which under his editorship has become premier periodical for this field. He runs the Australian Rock Art Research Association. He is Convenor of the International Federation of Rock Art Organizations. He may pay some of the bills himself for these outfits. He holds strong and highly individual opinions on aspects of rock-art, on the nature of archaeological knowledge, on the likely antiquity of rock-art in varied regions, on the weaknesses of colleagues in the field. (I have tried diligently to grasp his distinction between obsolete archaeology with its false models - this seems to define what most of us do - and the different taphonomic model for good understanding based on real science this seems to define what he does.)

In 1992, the large and excellent second Australian rock-art congress was held at Cairns. ROBER' BEDNARIK was its energetic organizer, as he had been for the first in Darwin and is for the next in Sydney. A high point of the Cairns programme was the announcement by Aboriginal elders of a Queensland community that a scientific dating showed that the rock-paintings in their country were astonishingly ancient - even the oldest in the world. It was calculated to make the front page of the next day's Sydney Morning Herald, and I was glad when it did not. Why? Because I thought it was so unfair, to offer good people - whose knowledge was nil of the full range of difficult technical and geochemical issues on which that dating study had to depend - that statement as if an unqualified fact, to see them take unreserved pride in it, and to have them offer it to the world as secure knowledge.

Among the more archaic Australian rockpainting traditions, it is agreed, are the old Bradshaw figures, faded into a mulberry colour, of the Kimberley region. The fieldwork there is done, and the first AMS dates have come through. Suppose those numbers are, say, 3100 or 3900 years b.p. for organics in paint, not half that age for matter lying over the paint - that is, suppose the numbers place the Bradshaws surprisingly late, just as the numbers have done in Portugal. Will we hear the matching claims, that rock-art in Australia can be no more than 5000 years old? Or will the top of these facts be sent spinning off quite another way, for here a different direction is desired? I look forward to the scientists' statements on this matter. (ANTIQUITY was asked some time ago if we would like to publish reports on the Kimberley work: we would.)

I have noticed the responsibilities of EDP. What are the responsibilities of IFRAO?* Members of its constituent organizations may like to enquire if Dr Bednarik's consulting work in Portugal was in his personal capacity as an individual researcher, or in his official capacity as Convenor of IFRAO. The outfit's mission, as printed on its letterhead, is: 'IFRAO facilitates international co-operation, initiates and pursues common policies and projects, and acts as an altruistic and cohesive medium for the discipline.'

\footnotetext{
* The 23 constituents of the International Federation of Rock Art Organizations are: American Committee to $\mathrm{Ad}$ vance the Study of Petroglyphs and Pictographs; American Rock Art Research Association; Associaçao Portuguesa de Arte e Arqueologia Rupestre; Association des Amis de l'Art Rupestre Saharien; Association pour le Rayonnement de l'Art Pariétal Européen; Australian Rock Art Ressearch Association; Centar za Istrazuvanje na Karpestala unet nost i Praistorijata na Makedonija; Centro de Investigación do Arte Rupestre del Uruguay; Centro Studi c Museo d'Arte Preistorica; Comite de Investigación del Arte Rupestre de la Sociedad Argentina de Antropología; East African Rock Art Research Association; Gesellschaft für Vergleichende Fclsbildforschung; Group de réflexion sur les méthodes d'étude de l'art parićtal paléolithique; Indian Rock Art Research Association; Institutum Canarium; Japan Petrograph Society; Rock Art Association of Canada; Rock Art Association of Manitoba; Rock Art Research Association of Canada; Rock Art Society of India; Sociedad de Investigación del Arte Rupestre de Bolivia; Società Cooperativa Archaeologica le Orme dell'Uomo; Société Préhistoriquc Ariège-Pyrénées; Southern African Rock Art Research Association.
} 
Noticeboard

ANTHONY SINCLAIR (Unjversity of Liverpool, England) has become Assistant Editor of ANTIQUITY, succeeding CYPRIAN BROODBANK, whose term has ended.

Call for papers

25 April 1996

Geology and Geochemistry in Archaeology. A one-day symposium to be held at the Open University, Milton Keynes, UK, sponsored by the Open University, the Mineralogical Society and the Geochemistry Group, which will bring together archaeologists and geologists to discuss recent applications of geology, geochemistry and mineralogy in archaeology, with emphasis on nondestructive, field-portable methods of artefact chararterization.

Olwen Williams-Thorpe, Dept of Earth Sciences, The Open University, Milton Keynes MK 7 6AA, England; (0)1908-655147 tel.; (0)1908-655151 FAX;

O.Williams-Thorpe@open.ac.uke-mail.

Call for papers

30 July-4 August 1996 (probably)

Vanuatu National Museum-ANU-ORSTOM conference on 'The western Pacific, 5000-2000 BP: colonisations and transformations', to be held in Port Vila, Vanuatu, to coincide with the opening (date not yet finalised) of a major exhibition of Vanuatu ethnographic arts at the newly constructed Vanuatu National Museum and Independence Day celebrations on 30 July. Probable themes include: What Lapita is and isn't; sources of Micronesian colonisation; ways of presenting the deep past to a Pacific audience; lots more. Hot-from-the-field reports of recent research also welcome.

Jean-Christophe Galipaud (till 10 January 1996): National Museum of New Zealand, Dept of Archaeozoology, PO Box 467, Wellington, New Zealand; (0)4 3877419 FAX.; (0)4 3877413 tel.; GALIPAUD@AOTAHI.MONZ.GOVT.NZ email. (After 10 January 1996): ORSTOM, PO Box 76, Port Vila, Vanuatu; 678-23276 FAX; 678-22268 tel.; GALIPAUD@VANUATU.ORSTOM.FR email.

Matthew Spriggs (after 23 December 1995): ANH, RSPAS, ANU, Canberra ACT 0200, Australia; (0)6-249-4917 FAX; SPRIGGS@COOMBS.ANU.EDU.AU email.

\section{Correction}

We reprint here, with apologies and much reduced, the map which ought to have appeared as FIGURE 1 (p. 338) of Healy et al.'s article in the June 1995 issue (pp. 337-48).

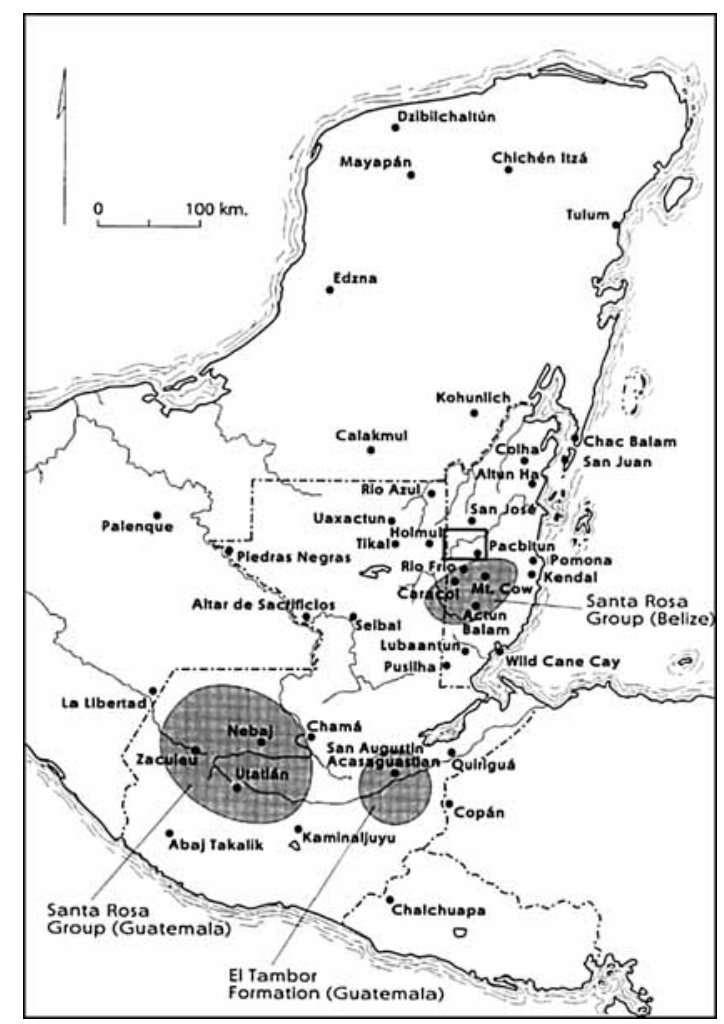

FIGURE 1. Map of the Maya subarea indicating archaeological sites in the text and slate-bearing formations (shaded).

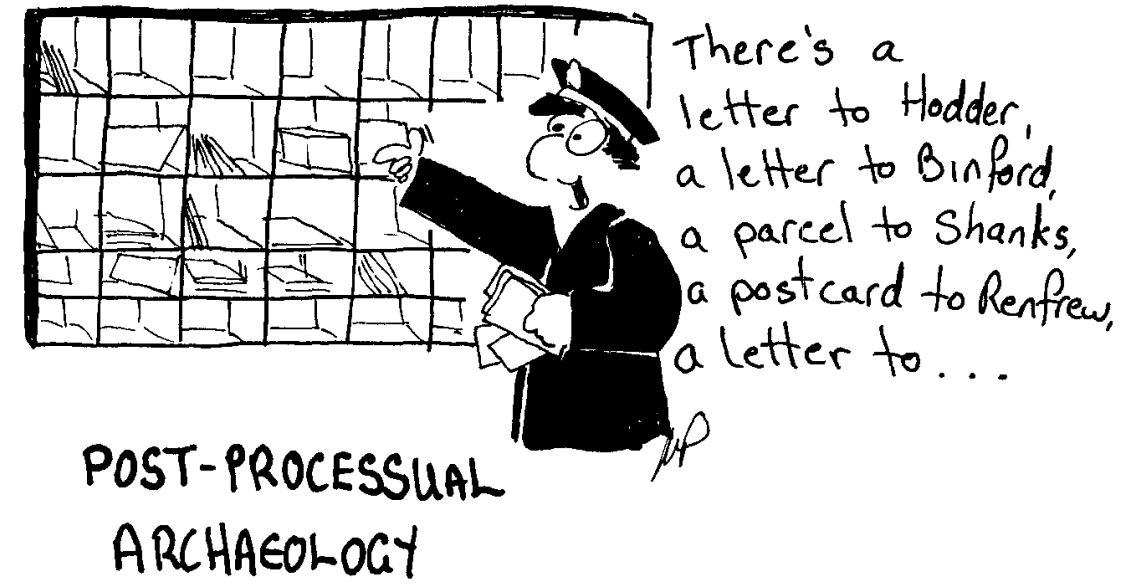

